\title{
Effect of shark cartilage derived protein on the NK cells activity
}

\author{
Afshar Bargahi ${ }^{1}$, Zuhair M. Hassan², A. Rabbani ${ }^{3}$, Ladan Langroudi², S. H. Noori ${ }^{4}$, and Elahe Safari ${ }^{2}$ \\ ${ }^{1}$ Research Center for Marin Medicine Biotechnology, Persian Gulf Biomedical Institute, Bushehr University of Medical \\ Sciences, Bushehr, Iran, ${ }^{2}$ Department of Immunology, School of Medical Sciences, Tarbiat Modares University, Tehran, \\ Iran, ${ }^{3}$ Institute of Biochemistry \& Biophysics, University of Tehran, Tehran, Iran, and ${ }^{4}$ Department of Biochemistry, School \\ of Medical Sciences, Tarbiat Modares University, Tehran, Iran
}

\begin{abstract}
Context: Shark cartilage has been used for its beneficial effects on various diseases. There are evidences, that shark cartilage stimulates cellular and humoral immune responses, which makes it an anti-tumor and immunomodulator candidate.

Objective: The immunostimulatory effect of shark cartilage derived proteins on the cytotoxic activity of natural killer (NK) cells from healthy human peripheral blood mononuclear cells was studied.

Material and methods: The shark cartilage was extracted and its bioactive proteins were purified using ion-exchange chromatography (DE-52) and sequential fractionation on Amicon ultrafiltration membranes. The effect of each protein fraction on the modulation of cytotoxic activity of NK cells, as effectors, against K562, as target cells, was assayed by enzymatic lactate dehydrogenase test.

Results: The most immunostimulatory effect on the cytotoxic activity of NK cells was observed for AR10 fraction, containing proteins with molecular weight of about $14.5 \mathrm{kDa}$ on the reducible discontinuous sodium dodecyl sulfate polyacrylamide gel electrophoresis.

Discussion: Among the examined shark cartilage derived proteins, the most immunostimulatory effects on the NK cells cytotoxicity was found for AR10 fraction with molecular weight of about $14 \mathrm{kDa}$. We propose-the direct interactions of shark cartilage derived proteins with NK cells surface receptors may lead to the enhancing in the cytotoxic activity of NK cells.

Conclusion: Thus AR10 fraction, proteins of about $14.5 \mathrm{kDa}$, has a novel immunostimulatory effect on the NK cells activity in vitro and if confirmed by in vivo trials, it may lead to its future clinical applications as, immunotherapy of cancer, HIV, and augmentation of host immune system related immunodeficiency disorders.
\end{abstract}

Keywords: Immunostimulation, purification, shark cartilage, K562, NK cell

\section{Introduction}

The endoskeleton of shark is completely cartilaginous and non-mineralized. Cartilage contributes up to the $6-8 \%$ of the total body weight of shark..$^{(1)}$ The extracellular component of cartilage is largely composed of cells, which are isolated in small cavities within the cartilage matrix. Cartilage is an interesting and unique tissue that is avascular and relatively tumor resistant. ${ }^{(2)}$ Traditionally, the shark cartilage has been used for its beneficial effects on the rheumatoid arthritis, progressive systemic sclerosis, neurovascular glaucoma, osteoarthritis, and some other diseases. ${ }^{(3,4)}$ There are also anti-tumor bioactive ingredients in shark cartilage. ${ }^{(5-8)}$ There are evidences, that shark cartilage stimulates cellular, and humoral immune responses, which makes it an anti-tumor and immunomodulator candidate. ${ }^{(9,10)}$ The effects of cartilage extracellular matrix were reported to augment the immune response and activation of T-cells in the absence of monocytes and antigen-presenting cell. ${ }^{(11)}$ Cartilage derived materials interact directly with the integrin sur-

Address for Correspondence: Z.M. Hassan, Department of Immunology, School of Medical Sciences, Tarbiat Modares University, P.O. Box: 14115-111, Tehran, I.R. Iran. E-mail: hasan_zm@modares.ac.ir

(Received 03 May 2010; revised 08 June 2010; accepted 08 June 2010) 
face receptors of T-cells and increase the expression of interleukin 2 (IL-2), IL-4, interferon $\gamma$ (IFN- $\gamma$ ), and tumor necrosis factor $\alpha$ cytokine genes independent of T-cell receptor pre-sensitization. ${ }^{(12)}$ The elevated expression of cytokines, especially IL-2, and IFN- $\gamma$, activates the natural killer (NK) cells cytotoxicity. ${ }^{(13)}$ Therefore the activated NK cells can bind to and kill neoplastic or infected target cells without prior immunization of host. ${ }^{(14)}$ Certain materials in the cartilage of other sources can be used as biological response modifiers. Since these can also induce tumor killing of NK cells. ${ }^{(15,16)}$ According to the findings of the present study, certain proteins from shark cartilage can augment and stimulate the cytotoxic activity of NK cells against K562, as target cells in vitro.

\section{Materials and methods}

\section{Materials}

All chemical substances were of analytical or molecular biology grade. RPMI-1640, fetal calf serum (FCS), $\mathrm{N}$-(2hydroxyethyl) piperazine- $N^{\prime}$-(2-ethanesulfonic acid) (HEPES), streptomycin, L-glutamate, collagenase, benzamidine- $\mathrm{HCl}$, guanidine- $\mathrm{HCl}, \mathrm{N}$-ethylmaleimide, penicillin, dialysis tubes, phenyl methyl sulfonyl fluoride (PMSF), ethylenediaminetetraacetic acid (EDTA), nicotinamide adenine dinucleotide $\left(\mathrm{NAD}^{+}\right)$, phenazine methosulfate, and $(+)$ L-lactate and iodonitrotetrazolium formazan (INT) were purchased from Sigma-Aldrich (Milwaukee, WI). Iodoacetic acid, TRIS/HCl, acrylamide, and bisacrylamide were purchased from Merck Company. 6-Aminohexanoic acid was purchased from Fluka Company (Germany). Ultrafiltration steered cell apparatus (Model 405) and ultrafiltration membranes were obtained from AmiconMillipore Company (USA). Diethylaminoethyl cellulose (DE-52) was purchased from Whatman International Ltd (Maidstone, UK). Protein molecular weight markers were purchased from Pharmacia Biotech (USA). Tissue culture flasks and 96-wells microplates were obtained from Nunc (Denmark).

\section{Preparation of target cells}

Human chronic myeloid leukemia (K562) is a standard line showing permanent sensitivity on the stage of growth. ${ }^{(17,18)}$ Thus in this study, K562 cells were used as target cells to study the effects of shark cartilage derived proteins on the NK cell's cytotoxic activity. The K562 cells were grown in RPMI-1640 medium supplemented with $5 \%$ FCS, $100 \mu \mathrm{g} / \mathrm{mL}$ streptomycin, $100 \mathrm{IU} / \mathrm{mL}$ of penicillin, and $2 \mathrm{mM}$ of L-glutamate, in the tissue culture flasks at $5 \% \mathrm{CO}_{2}, 95 \%$ humidified incubator at $36^{\circ} \mathrm{C}$. Before using, cells were washed twice in RPMI-1640 containing $5 \%$ FCS, counted and suspended in the same medium containing 5\% FCS, as the stock of target cells. ${ }^{(13,19)}$ The cell viability in all experiments was $>95 \%$ using trypan blue exclusion test.

\section{Preparation of the effector's cells}

Human peripheral blood mononuclear cells (hPBMN) were obtained from the healthy human volunteers, hepa- rinized, and mixed with an equal volume of phosphate buffer saline (PBS), 0.2 M, pH 7.4. The cell suspension was centrifuged on the lymphoprep continuous gradient at $900 \mathrm{~g}$ for $15 \mathrm{~min}$, washed three times in the same buffer and suspended in RPMI-1640 medium containing $5 \%$ FCS. The influence of macrophages was excluded by incubation of these cells on the tissue culture flasks in $5 \%$ $\mathrm{CO}_{2}, 95 \%$ humidified incubator at $37^{\circ} \mathrm{C}$ for $2 \mathrm{~h}$. Thus in our study, the NK cells were depleted from the macrophages and monocytes. ${ }^{(20)}$ So the only present cells were $\mathrm{B}, \mathrm{T}$, and NK cells. The stocks of NK cells were prepared at $1 \times 10^{6}$ cells/mL concentrations in the same medium. ${ }^{(13)}$

\section{Activation of the NK cells by shark cartilage derived proteins}

In all of the biological assessments the resulted protein fractions were dialyzed against PBS buffer, $0.2 \mathrm{M}, \mathrm{pH} 7.4$ at $4^{\circ} \mathrm{C}$, sterilized and kept frozen at $-20^{\circ} \mathrm{C}$ until use. The NK cells were plated at $1 \times 10^{5}, 2 \times 10^{5}$, and $4 \times 10^{5}$ cells/ well densities in the 96 -wells round-bottomed microtiter plates in the RPMI-1640 complete medium in triplicates. For stimulation of NK cells, certain doses of shark cartilage protein fractions, from each purification step, were added to the incubation medium of the NK cells and incubated in the $5 \% \mathrm{CO}_{2}, 95 \%$ humidified incubator at $37^{\circ} \mathrm{C}$ for $18 \mathrm{~h}$.

\section{Bioassay of NK cells cytotoxicity by enzymatic lactate dehydrogenase test}

The enzymatic lactate dehydrogenase ( $\mathrm{LDH})$ test was used to assay the NK cells cytotoxic activity against target K562 cells. ${ }^{(19)}$ So, an aliquot of the target cells was removed from stock of K562 cells, which were previously prepared in RPMI-1640 complete medium and washed twice with RPMI-1640 medium. Then $2 \times 10^{4}$ cells/well of viable K562 cells were plated in each well of the enzymelinked immunosorbent assay 96 wells (ELISA 96-wells) round-bottomed microplates containing pre-treated NK cells with certain doses of shark cartilage proteins, at the effecter/target ratios of $5 / 1,10 / 1$, and $20 / 1$. The cells were mixed gently and incubated in the $5 \% \mathrm{CO}_{2}$, $95 \%$ humidified incubator at $37^{\circ} \mathrm{C}$ for $4 \mathrm{~h}$. Then the plates were centrifuged at $900 \mathrm{~g}$ for $10 \mathrm{~min}$ and $0.1 \mathrm{~mL}$ of the supernatant was transferred to the corresponding wells of the ELISA 96-wells flat-bottomed microplates and subsequently, $0.1 \mathrm{~mL}$ of the LDH enzyme substrate mixture (Tris/ $\mathrm{HCl} 200 \mathrm{mM}, \mathrm{pH} 8.2$, (+) L-lactate $5.4 \times 10^{-2} \mathrm{M}$, Phenazine methosulfate $2.8 \times 10^{-4} \mathrm{M}, \mathrm{NAD}^{+} 1.3 \times 10^{-3} \mathrm{M}$, INT $6.6 \times 10^{-4} \mathrm{M}$ ) was added to each well. After $3 \mathrm{~min}$ of reaction development, the absorbance at $390 \mathrm{~nm}$ was monitored by ELISA microtiter plate reader instrument (Lab System, Multiscan MS). The percent of NK cells cytotoxicity (\%C) was calculated using the following equation:

$$
\% \mathrm{C}=\frac{\mathrm{E}-\mathrm{S}}{\mathrm{M}-\mathrm{S}}
$$

\%C is the change in $\mathrm{LDH}$ activity, which is a direct index of the released LDH enzyme from lysed target K562 cells. 
$\mathrm{E}$ is the experimental release of $\mathrm{LDH}$ enzyme from the K562 cells. S is the spontaneous release of LDH enzyme from the target cells that were incubated in the absence of effector cells. $\mathrm{M}$ is the maximum release of LDH enzyme from the sonicated target cells.

\section{Extraction and purification of shark cartilage derived proteins \\ Extraction}

Shark cartilage slices were separated and cleaned from peripheral tissues using a proteolytic enzyme, alcalase, in $0.01 \%$ HEPES buffer, $\mathrm{pH} 8.5$ for $60 \mathrm{~min} .{ }^{(5)}$ The peripheral collagens were removed by enzymatic method using collagenase according to the method of Lafuma et al. ${ }^{(21)}$ The peripheral fats of the cartilage tissue were removed using a solution of chloroform-methanol by Folch method. ${ }^{(22)}$ Then cartilage tissue was cut into small pieces, lyophilized and pulverized and $10 \mathrm{~g}$ of the grounded cartilage was extracted in $100 \mathrm{~mL}$ of $0.1 \mathrm{M}$ sodium acetate buffer ( $\mathrm{pH}$ 4.8) containing $4 \mathrm{M}$ guanidine-HCL in the presence of protease inhibitors cocktail (EDTA $6.25 \mathrm{mM}$, PMSF $1 \mathrm{mM}$, benzamidine- $\mathrm{HCl} 0.25 \mathrm{mM}$, 6 -aminohexanoic acid $0.25 \mathrm{mM}$, iodoacetic acid $2 \mathrm{mM}$, $\mathrm{N}$-ethylmaleimide $10 \mathrm{mM}$ ) at $4^{\circ} \mathrm{C}$ for $48 \mathrm{~h} .{ }^{(23)}$ After centrifugation at $60,000 \mathrm{~g}$ for $60 \mathrm{~min}$, the supernatant was concentrated and its protein concentration was assayed by Bradford method. ${ }^{(24)}$

\section{Purification of shark cartilage proteins by ion-exchange chromatography}

An aliquot of the supernatant extract was applied on the ion-exchange column chromatography $(1.6 \times 20 \mathrm{~cm})$, DE-52, Whatman, pre-equilibrated with $50 \mathrm{mM}$ Tris/ $\mathrm{HCl}$ buffer, pH 7.0 containing $7 \mathrm{M}$ urea at $4^{\circ} \mathrm{C} .{ }^{(25)}$ After elution of the unbound materials as fraction $\mathrm{A}$, the bound materials, as fraction B were eluted by one step salt gradient of same buffer but containing $1 \mathrm{M} \mathrm{NaCl}$. The effluent fractions containing proteins were pooled as $\mathrm{A}$ and $\mathrm{B}$ by monitoring the absorbance at $230 \mathrm{~nm}$ using Uv-Vis spectrophotometer instrument (Perkin-Elmer Lambda-2; Perkin Elmer \& co. GmbH). Subsequently the protein concentrations of the unbound and bound materials, corresponding to $\mathrm{A}$ and $\mathrm{B}$ fractions were determined by Bradford method. ${ }^{(24)}$

\section{Purification of shark cartilage proteins by ultrafiltration}

The resulting A fraction, from ion-exchange chromatography having more immunostimulatory effects on the NK cells cytotoxic activity was further purified by Amicon ultrafiltration stirred cell model 402 apparatus over an Amicon's XM-300 membrane. The obtained fractions with the molecular weights of AR300, MW > $300 \mathrm{kDa}$ and AF300, MW < $300 \mathrm{kDa}$ were used in bioassay of NK cell's cytotoxic activity as described above. The resulted AF300 fraction, having more immunostimulatory effect on the NK cells cytotoxic activity was further fractionated to AR100, $100 \mathrm{kDa}<\mathrm{MW}<300 \mathrm{kDa}$; AR50, $50 \mathrm{kDa}<$ $\mathrm{MW}<100 \mathrm{kDa}$; AR10, $10 \mathrm{kDa}<\mathrm{MW}<50 \mathrm{kDa}$, and AF10,
MW $<10 \mathrm{kDa}$ by sequential ultrafiltration on Amicon's XM-100, XM-50, and YM-10 membranes, respectively. The immunostimulatory effects of each fraction were assayed by the enzymatic LDH test as described above.

\section{Purification of shark cartilage 14 kDa protein by Sephadex G-50 chromatography}

Farther purify the $14 \mathrm{kDa}$ of the AF10 fraction Sephadex G-50 was used. The dried gel in sufficient amount was incubated in distilled water for $72 \mathrm{~h}$ at $4^{\circ} \mathrm{C}$. It was loaded onto the column $(12 \times 1 \mathrm{~cm})$. Then the column was equilibrated with urea $5 \mathrm{M}$. the sample was applied to the column at a flow rate of $0.1 \mathrm{~mL} / \mathrm{min}$. samples was collected as elution of $1 \mathrm{~mL}$. Absorbance values of the elution tubes were determined at $280 \mathrm{~nm}$. Fractions dialyzed against PBS buffer with pH 7.4 and sterile with filter $0.02 \mu \mathrm{m}$. Proteins were tested by limulus amebocyte lysate test for endotoxin contaminations and it was free.

\section{Sodium dodecyl sulfate polyacrylamide gel electrophoresis}

The shark cartilage bioactive protein fractions, A, AR300, AF300, and AR10, with the most immunostimulatory effects on the cytotoxic activity of NK cells were run on the discontinuous (stacking 5\% and separating 10\%) reducible sodium dodecyl sulfate polyacrylamide gel electrophoresis (SDS-PAGE) as described by the Schägger et al., ${ }^{(26)}$ and silver stained by the Morrissey method. ${ }^{(27)}$

\section{Statistical analysis}

Results were shown as mean \pm SD for $n=3$ experiments. Student's unpaired $t$-test was used for the estimation of the significances among the means. The $p<0.05$ was taken as significant.

\section{Results}

At the present research the isolation, partial purification, and immunostimulatory effects of unique shark cartilage derived protein fractions on the cytotoxic activity of NK cells against K562 cells were studied. Our in vitro experiments excluded the possible direct toxic effects of the shark cartilage materials on the K562 or NK cells.

\section{Evaluation the ion-exchange purified shark cartilage protein on NK cells}

Shark cartilage homogenate was fractionated to A and B by ion-exchange chromatography as described in the methods (Figure 1A). In the pre-treatment stage for assessment of the NK cell's cytotoxic activity against K562 cells, $19.1 \mu \mathrm{g} /$ well of each A and B fractions was added to the NK cells culture medium. Then, the activated NK cells were targeted against the $\mathrm{K} 562$ cells at $\mathrm{E} / \mathrm{T}=5 / 1$, $10 / 1$, and $20 / 1$. The cytotoxic activity of the pre-treated NK cells was assayed by enzymatic LDH test as described in methods. The cytotoxic activity of the pre-treated NK cells with fraction A was significantly higher than that of the fraction B (Figure 1B). 


\section{Evaluation the ultrafiltration purified shark cartilage proteins on NK cell activity}

Further purifications were achieved by ultrafiltration of the fraction A that was obtained from ion-exchange column on the XM-300 ultrafiltration membrane. The resulted AF300 and AR300 fractions, corresponding to the molecular weights of MW $<300 \mathrm{kDa}$ and $\mathrm{MW}>300 \mathrm{kDa}$ were obtained. Cytotoxic activities of the pre-treated NK cells with $16.7 \mu \mathrm{g} /$ well of each AF300 and AR300 fractions were compared and the results indicated that cytotoxic activity of the NK cells pre-treated with AF300 fraction was higher than that of BF300 (Figure 2A). The AF300 fraction with more immunostimulatory effect on the cytotoxic activity of NK cells was further purified by sequential fractionations on XM-100, XM-50, and YM-10 Amicon's ultrafiltration membranes. Then, $3.6 \mu \mathrm{g} /$ well of each AR100, AR50, AR10, and AF10 protein fractions were added to the NK cells incubation medium in the
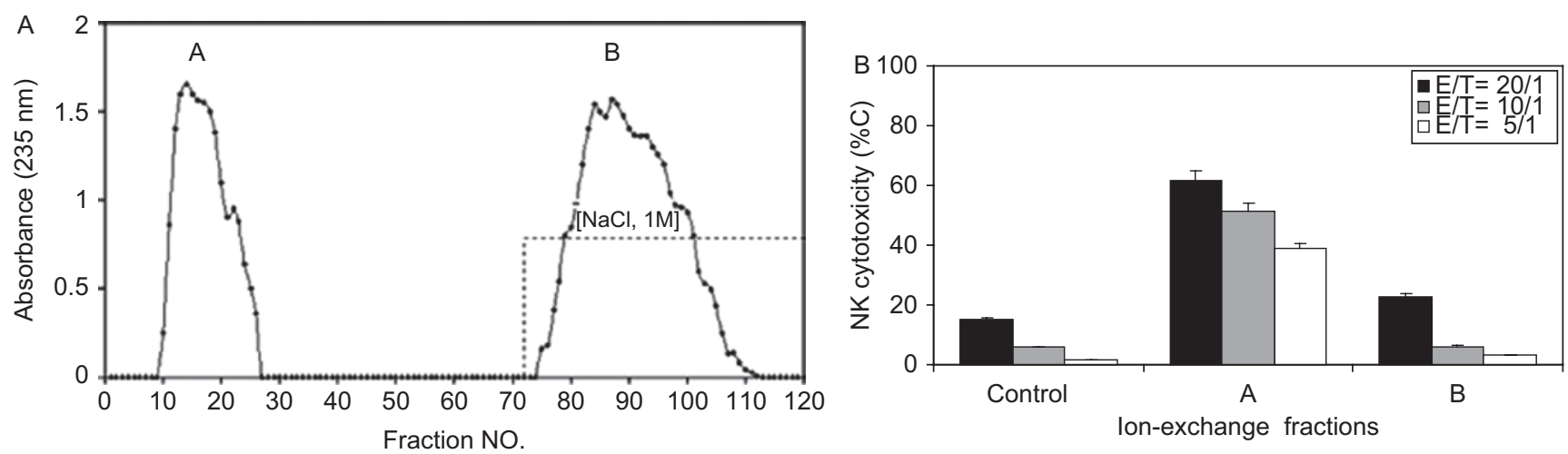

Figure 1. (A) Ion-exchange chromatography (DE-52) of crude extract of shark cartilage. The A and B protein fractions were pooled by measuring the eluate absorbance at $235 \mathrm{~nm}$ as indicated by $(-)$. Then the bound materials were eluted by one step salt gradient of $\mathrm{NaCl}$ $1 \mathrm{M}$ as indicated by (---). (B) Cytotoxic activity of NK cells pre-treated with $19.1 \mu \mathrm{g} /$ well of Shark cartilage derived A and B protein fractions obtained from anion-exchange chromatography. Effectors/target $=20 / 1,10 / 1,5 / 1 . P<0.05 . N=3$.

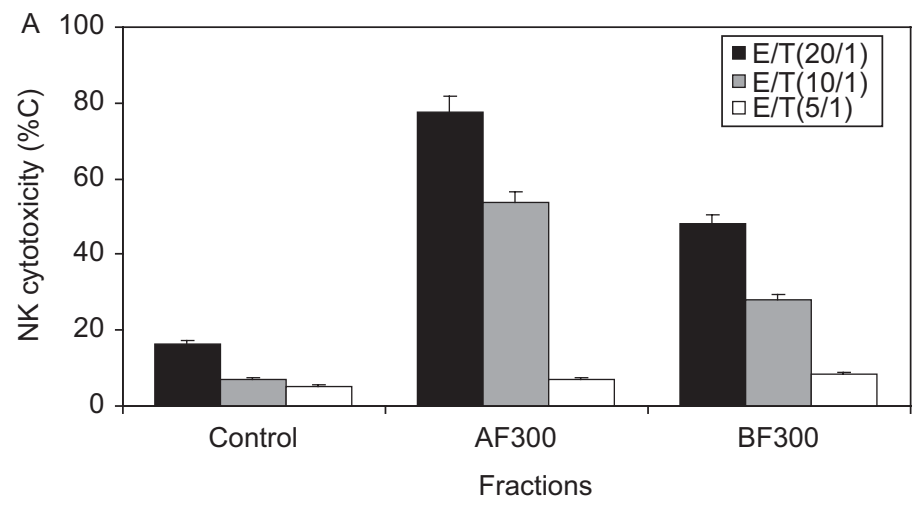

C

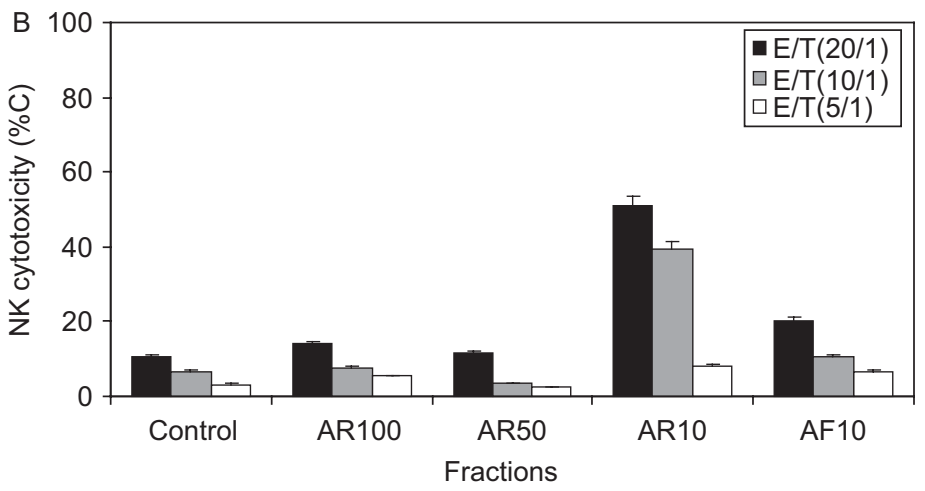

$(30 \mathrm{KDa})$

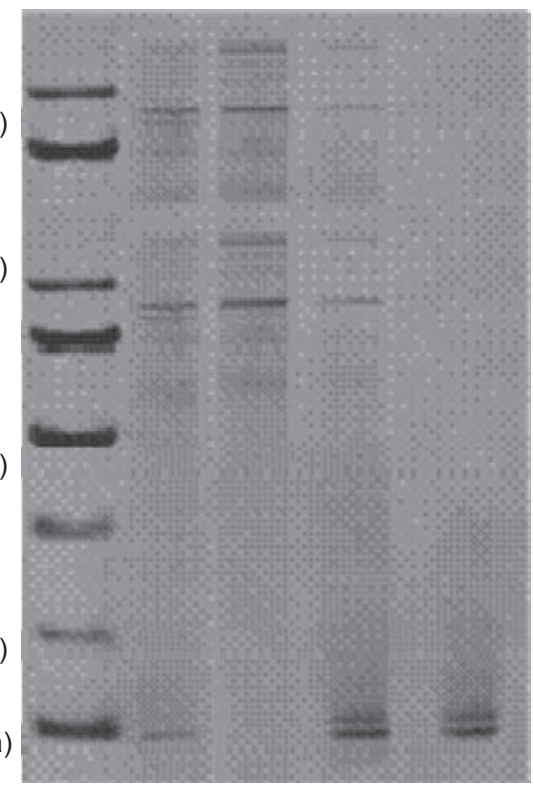

Figure 2. (A) Cytotoxic activity of NK cells pre-treated with $16.7 \mu \mathrm{g} /$ well of shark cartilage, AF300 and AR300 protein fractions. Effector/target ratio $=20 / 1,10 / 1,5 / 1 . P<0.05 . N=3$. (B) Cytotoxic activity of NK cells pre-treated with $3.6 \mu \mathrm{g} /$ well of shark cartilage, AR100, AR50, AR10, and AF10 protein fractions. Effectors/target ratio $=20 / 1,10 / 1,5 / 1 . P<0.05$. $N=3$. (C) Sodium dodecyl sulfate polyacrylamide gel electrophoresis of bioactive, A, AR300, AF300 and AR10 shark cartilage derived protein fractions. The purified final bioactive proteins fraction, AR10, migrated with apparent molecular weight of $14.5 \mathrm{kDa}$. The position and molecular weights in kilodalton (kDa) for marker proteins are as: phosphorylase-b $94 \mathrm{kDa}$, Bovine serum albumin $67 \mathrm{kDa}$, Ovalbumin $43 \mathrm{kDa}$, carbonic anhydrase $30 \mathrm{kDa}$, soybean trypsin inhibitor $20 \mathrm{kDa}, \alpha$-lactalbumin $14.4 \mathrm{kDa}$. 
pre-treatment stage. The results were assayed for their comparative immunostimulatory effects on the NK cells by the enzymatic LDH test. The highest immunostimulatory effects on the NK cells cytotoxic activity was observed for AR10 (Figure 2B). In each purification step for the assessment of the protein purity, the selected bioactive protein fraction was subjected to reducible discontinuous SDS-PAGE gel electrophoresis as described in methods. After silver staining, the electropherogram revealed the existence of two immunostimulatory proteins in the final purified protein fraction, (AR10) with apparent molecular weight of about $14.5 \mathrm{kDa}$. (Figure 2C).

\section{Evaluation the Sephadex G-50 purified shark cartilage $14 \mathrm{kDa}$ protein on NK cell activity}

In order to evaluate the immunomodulation activity of the purified $14 \mathrm{kDa}$ shark cartilage on NK cell activity, the AF10 fraction was further purified by Sephadex G-50 and the result in Figure 3B showed that SDS-PAGE gel electrophoresis has one band of $14 \mathrm{kDa}$ purified shark cartilage. The NK cells cytotoxic activity was evaluated and the results in Figure 3A indicated a significant increase in the NK activity comparing to control group.

\section{Discussion}

Over the recent years, much attention in the scientific and popular press has been focused on the anti-angiogenic and anti-neoplastic effects of shark cartilage extract. $^{(5)}$ Since the discovery that sharks rarely gets cancer, ${ }^{(1)}$ some progress has been made in identifying the various unusual compounds present in shark cartilage. Now, in the beginning of the 21st century, it is clearly known that there are some anti-angiogenic compounds in shark cartilage that make it much resistant to tumors. To date, a limited number of clinical trials have been undertaken to investigate the anti-tumor effects of shark cartilage and it has been shown that oral administration of shark cartilage results in reduction of tumor size and causes an improvement in the quality of life. ${ }^{(5)}$ In view of the popular interest in shark cartilage, as an anti-cancer agent and the limited supporting scientific data as to its efficacy, we decided to investigate the effects of shark cartilage on immune response and specifically on the activation of NK cells.

In this research comparative studies were performed on both the semi purified and purified cartilages and its effect on NK cell activity. Shark cartilage was extracted, partially purified by Amicon ultrafiltration membrane and further purified by chromatography, ion-exchange and Sephadex G-50. The results showed that the most potent fraction that augments immune response was low molecular weight fraction (14-15 kDa), protein. The immunostimulatory effect of shark cartilage proteins on the cytotoxic activity of NK cells obtained from healthy hPBMNs against K562 target cells was studied.

In the first step we run the shark cartilage extract on ion-exchange chromatography, among the examined shark cartilage derived proteins, the most immunostimulatory effects on the NK cells cytotoxicity was found in the anionic fraction (A) fraction. Cationic fraction showed no significant increase in NK activity. In farther purification, fraction A was run on Amicon ultrafiltration and we noticed that the NK activity was stimulated by fraction AR10 (anionic residue of the Amicon membrane $10 \mathrm{kDa}$ ). We noticed a significant increase in NK cell activity after Amicon purification comparing with ion-exchange purification, although the concentration of shark cartilage used in each well after ion exchange $(19.1 \mu \mathrm{g} /$ well $)$ was higher than in the after Amicon ultrafiltration (3.61 $\mu \mathrm{g} /$ well).

In the complete purified molecules by Sephadex 50 evaluated with SDS-PAGE and incubated with NK cells could augment the natural activity comparing to control group.

NK cells play a major role in the host-rejection of both tumors and virally infected cells. NK cells are cytotoxic; small granules in their cytoplasm contain special proteins such as perforin and proteases known as granzymes. ${ }^{(18)}$

The mechanism of immunostimulatory effects of shark cartilage proteins is still unknown. Although direct interaction of cartilage derived proteins with B-cells is not yet known, but T-lymphocytes have receptors for cartilage extracellular matrix proteins. ${ }^{(11)}$ The interac-

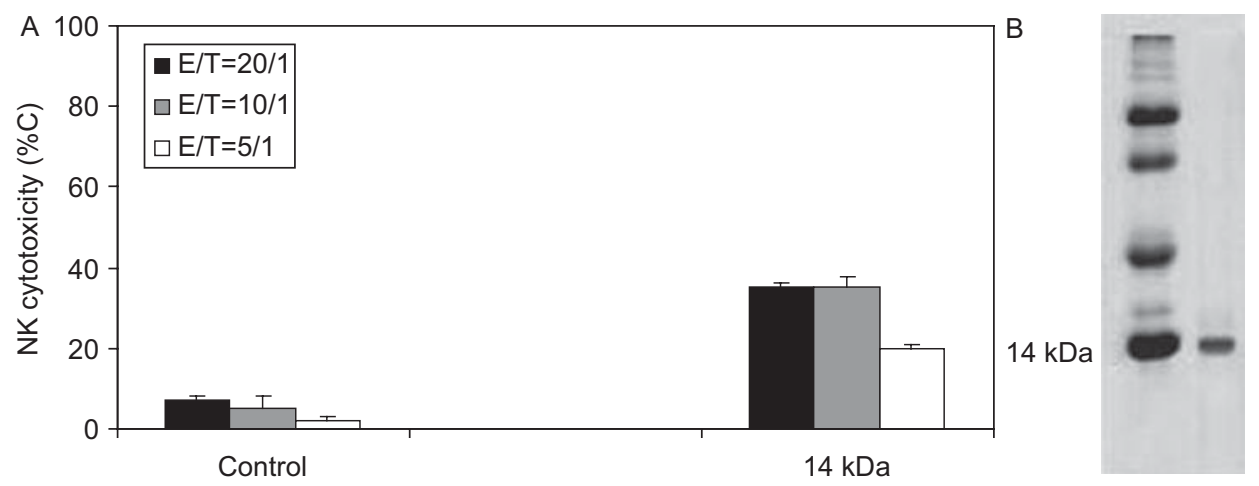

Figure 3. (A) Cytotoxic activity of NK cells pre-treated with $2 \mu \mathrm{g} /$ well of shark cartilage $14 \mathrm{kDa}$ protein obtained from Sephadex G-50 chromatography. Effectors/target $=20 / 1,10 / 1,5 / 1 . P<0.05 . N=3$. (B) Sodium dodecyl sulfate polyacrylamide gel electrophoresis of the $14 \mathrm{kDa}$ shark cartilage. 


\section{A. Bargahi et al.}

tion of these receptors with cartilage proteins leads to an increase in the concentrations of the certain T-cell cytokines. Because NK cells have receptors for these cytokines, this will increase the cytotoxic activity of the NK cells. ${ }^{(13)}$ However, we propose, the direct interactions of certain shark cartilage derived proteins with NK cells surface receptors may lead to the enhancement of the cytotoxic activity of NK cells. Thus the receptors for shark cartilage proteins may be found on the NK cells. Previous reports showed that heat shock protein 70 peptide interact with NK cells receptor CD94. ${ }^{(28)}$ Also A cooperative dialogue between NK cells and dendritic cells (DCs) has been recently described. They help each other to acquire their complete functions, both in the periphery and in the secondary lymphoid organs. ${ }^{(29)}$ In our recent study we understand that shark cartilage can activate DC CD40 as well as CD86.

We also suggest that the releasing of IL- 2 and IFN- $\gamma$ by $\mathrm{T}$ helper cell 1 lymphocytes into the incubation medium may cause an easier interaction between these proposed receptors on the NK cells and shark cartilage derived proteins in the obtained AR10 fraction. Thus AR10 fraction, containing proteins of about $14.5 \mathrm{kDa}$, has a novel immunostimulatory effect on the NK cells activity in vitro and if confirmed by in vivo trials, it may lead to its future clinical applications as, immunotherapy of cancer, HIV, and augmentation of host immune system against invading or autologous antigens in the related immunodeficiency disorders.

In order to identify and further characterize shark cartilage purified fraction, the protein was subjected to conventional $\mathrm{N}$-terminal sequence analysis. Determination of 23 amino acids from the $N$-terminal revealed sequence similarity to $\alpha$ parvalbumin. The sequence differs only in five positions compared to Leopard shark muscle parvalbumin, in nine positions from cat shark muscle parvalbumin, ${ }^{(30)} 12$ positions with chicken muscle ${ }^{(31)}$ and in nine positions with mouse muscle parvalbumin. But we found that the purified fraction $14 \mathrm{kDa}$ shark cartilage sequence was completely differs from chicken thymus parvalbumin. ${ }^{(32)}$

Previously we reported that the $14 \mathrm{kDa}$ molecular weight isolated from shark cartilage has an antiangiogenesis activity, ${ }^{(5)}$ stimulate the T-cell ${ }^{(10)}$ and today we noticed it can augment the NK cells in vitro. This molecule can be a candidate for immunotherapy.

\section{Declaration of interest}

This research was supported by the fund from Institute of Biochemistry Biophysics, University of Tarbiat modares and Bushehr University of Medical Sciences, Bushehr, Iran

\section{References}

1. Lee, A., Langer, R. Shark cartilage contains inhibitors of tumor angiogenesis. Science 1983, 221, 1185-1187.

2. Castronove, V., Dimitriadou, V., Savard, P., Rivie`re, M., Dupont, E. Cartilage as a source of natural inhibitors of angiogenesis. In:
Teicher, B.A., ed. Angiogenic Agents in Cancer Therapy. Totowa, NJ: Humana Press Inc, 1999; 175-183.

3. Fontenele, J.B., Araújo, G.B., de Alencar, J.W., Viana, G.S. The analgesic and anti-inflammatory effects of shark cartilage are due to a peptide molecule and are nitric oxide (NO) system dependent. Biol. Pharm. Bull. 1997, 20, 1151-1154.

4. Gomes, E.M., Souto, P.R.F., Felzenswalb, I. Shark cartilage containing preparation protects cells against hydrogen peroxide induced and mutagenesis. Mutat. Res. 1996, 367, 203-208.

5. Lane, J.W. Method and dosage unit for inhibiting angiogenesis or vascularization in animal using shark cartilage. United. States. Patent. 1991; USP No: 5,075,112.

6. Matheews, J. Media feeds frenzy over shark cartilage as cancer treatment. J. Natl. Cancer. Inst. 1993, 85, 1190-1191.

7. Hunt, T.J., Connelly, J.F. Shark cartilage for cancer treatment. Am. J. Health. Syst. Pharm. 1995, 52, 1756-1760.

8. Green, S. Shark cartilage therapy against cancer. Nutr. Health. Forum. 1997, 14, 1-5.

9. Raithaus, L.R. Shark liver for stimulating the immune system. United. States. Patent. 1998, USP No: 5,840,342.

10. Feyzi, R., Hassan, Z.M., Mostafaie, A. Modulation of $\mathrm{CD}(4)(+)$ and $\mathrm{CD}(8)(+)$ tumor infiltrating lymphocytes by a fraction isolated from shark cartilage: shark cartilage modulates anti-tumor immunity. Int. Immunopharmacol. 2003, 3, 921-926.

11. Gorski, A., Kupiec-Weglinski, J.W. Extracellular matrix proteins, regulators of T-cell functions in healthy and diseased individuals. Clin. Diagn. Lab. Immunol. 1995, 2, 646-651.

12. Gilat, D., Cahalon, L., Hershkoviz, R., Lider, O. Interplay of T-cells and cytokines in the context of enzymatically modified extracellular matrix. Immunol. Today. 1996, 17, 16-20.

13. Sosnowska, D., Mysliwski, A., Dzierzbicka, K., Kolodziejczyk, A.M. The in vitro effect of new muramyl peptide derivatives on cytotoxic activity of NK (natural killer) cells from hamsters bearing $\mathrm{Ab}$ Bomirski melanoma. Biotherapy 1997, 10, 161-168.

14. Garcia-Penarrubia, P., Cabrera, L., Alvarez, R., Galvez J. EffectorTarget interactions: saturability, affinity and binding isotherms. A study of such interactions in the human NK cell-K562 tumour cell system. J. Immunol. Methods. 1992, 155, 133-147.

15. Rosenberg, S.A. Immunotherapy of cancer using interleukin 2: current status and future prospects. Immunol. Today. 1988, 9, 58-62.

16. Sedlacek, H. H., Weidman, E., Seiler, F.R. Tumor immunotherapy using vibrocholerae neuraminidase(VCN). In: Jeljaszewicz, J., Pulverer, G., eds. Bacteria and Cancer. London, UK: Academic Press, 1982; pp. 246-290.

17. Bigda, J., Mysliwska, A., Mysliwska, J., Witkowski, J., Kmiec, Z., Bomirski, A. Natural killer sensitivity of four Bomirski melanoma variants. Cancer Lett. 1989, 44, 67-72.

18. Bigda, J., Mysliwski, A., Sosnowska, D., Romanowski, P., Bomirski, A. Natural killer sensitivity of tumor cells isolated from primary and metastatic lesions of four Bomirski melanoma variants. Clin. Exp. Metastasis 1991, 9, 57-65.

19. Korzeniewski, C., Callewaert, D.M. An enzyme-release assay for natural cytotoxicity. J. Immunol. Methods 1983, 64, 313-320.

20. Lemaire, I., St-Jean, M. Modulation of lung-associated natural killer activity by resident and activated alveolar macrophages. Immunol. Invest. 1990, 19, 27-40.

21. Lafuma, C., Moczar, M., Robert, L. Isolation and characterization of lung connective-tissue glycoproteins. Biochem. J. 1982, 203, 593-601.

22. Folch, J., Less, M., Sloane Stanley, H.G. A Simple method for the isolation and purification of total lipids from animal tissues. J. Biol. Chem. 1957, 226, 497-509.

23. Boils, S., Christopher, C., Handley, C. Passive loss of proteoglycan from articular cartilage explants. Biochim. Biophys. Acta. 1989, 993, 157-167.

24. Bradford, M.M. A rapid and sensitive method for the quantitation of microgram quantities of protein utilizing the principle of protein-dye binding. Anal. Biochem. 1976, 72, 248-254.

25. Front, P., Aprile, F., Mitrovic, D.R., Swann, D.A. Age-related changes in the synthesis of matrix macromolecules by bovine articular cartilage. Connect. Tissue Res. 1989, 19, 121-133. 
26. Schägger, H., von Jagow, G. Tricine-sodium dodecyl sulfatepolyacrylamide gel electrophoresis for the separation of proteins in the range from 1 to $100 \mathrm{kDa}$. Anal. Biochem. 1987, 166, 368-379. 27. Morrissey, J.H. Silver stain for proteins in polyacrylamide gels: a modified procedure with enhanced uniform sensitivity. Anal. Biochem. 1981, 117, 307-310.

28. Lui, G., Carrega, P., Ferlazzo, G. Principles of NK Cell/DC crosstalk: the importance of cell dialogue for a protective immune response. Transfusion. Med. Hemotherap. 2006, 33, 50-57.

29. Gross, C., Hansch, D. Interaction of heat shock protein 70 peptide with NK cells involves the NK receptor CD94. Biol. Chem. 2003, $384,267-279$.
30. Kuster, T., Staudenmann, W., Hughes, G.J., Heizmann, C.W. Parvalbumin isoforms in chicken muscle and thymus. Amino acid sequence analysis of muscle parvalbumin by tandem mass spectrometry. Biochemistry 1991, 30, 8812-8816.

31. Brewer, J.M., Wunderlich, J.K., Ragland, W.L. The amino acid sequence of avian thymic hormone, a parvalbumin. Biochimie 1990, 72, 653-660.

32. Rabbani-Chadegani, A., Abdossamadi, S., Bargahi A., YousefMasboogh, M. Identification of low-molecular-weight protein (SCP1) from shark cartilage with anti-angiogenesis activity and sequence similarity to parvalbumin. J. Pharm. Biomed. Anal. 2008, $46,563-567$. 